\title{
Predatory effects of Nephtys hombergii on other polychaetes in tidal flat sediments
}

\author{
Andreas Schubert \& Karsten Reise \\ II. Zoologisches Institut der Universität Göttingen, D-3400 Göttingen, Federal Republic of Germany \\ and \\ Biologische Anstalt Helgoland, Litoralstation, D-2282 List, Federal Republic of Germany
}

\begin{abstract}
On tidal flats near the island of Sylt in the North Sea the endobenthic polychaete Nephtys hombergiu (Savigny 1818) was added to enclosures. This caused a significant decline in other polychaetes, notably the deposit-feeders Scoloplos armiger (O. F. Müller) and Heteromastus filiformis (Claparede). These 2 were also the main prey components inside the guts of $N$. hombergiu. Occasionally, other predatory polychaetes were eaten and the amount of nematodes ingested increased with decreasing size of $N$. hombergii. Total prey consumption is estimated to be above $1 \mathrm{~g} \mathrm{C} \mathrm{m}^{-2} \mathrm{yr}^{-1}$ or at least one tenth of the consumption of all epibenthic predators together. Cages protecting $N$. hombergii from fish and birds caused its abundance to be elevated. The experiments suggest that $N$. hombergii is an important intermediate predator in the Wadden Sea.
\end{abstract}

\section{INTRODUCTION}

The structuring by predation of faunal assemblages in marine mud and sand is now a well-recognized phenomenon (Peterson 1979, Woodin 1983, Reise 1985a). Predator-exclusion experiments have repeatedly demonstrated strong effects of epibenthic predators on their endobenthic prey. Within the latter, however, there is additional internal predation composed of several trophic levels (Commito \& Ambrose 1985a, b). In a recent study, Commito \& Shrader (1985) report adding the predacious polychaete Nereis virens to enclosures, with the expectation of a decrease in other infaunal densities. Instead, there was a 2- to 6-fold increase. To explain this paradox, they speculated that $N$. virens preyed on an intermediate predator, the polychaete Nephtys incisa, thus allowing other infauna to increase.

In this study, we added Nephtys hombergii to field enclosures designed to evaluate its ability to reduce infaunal densities. $N$. hombergii has long been known to be a carnivore (Blegvad 1914, Clark 1962). Warwick et al. (1979), however, suspect that $N$. hombergü feeds to a considerable extent on microalgae. This may also be assumed indirectly from a study by McGrorty \& Reading (1984), who found $N$. hombergii to be an abundant primary colonizer in burrow pits apparently devoid of any other macrofauna. Here we provide evidence that adult $N$. hombergii significantly reduce the abundance of other polychaetes which serve as their principal prey. N. hombergui itself is susceptible to epibenthic predation.

\section{MATERIALS AND METHODS}

Study site. This investigation was conducted on tidal flats of Königshafen, a sheltered bay near the island of Sylt in the northern Wadden Sea. Physical conditions and biota are described in Wohlenberg (1937) and Reise (1985b). Tides are semidiurnal and the range is $1.8 \mathrm{~m}$. Our experiments were located at $0.4 \mathrm{~m}$ above mean low tide level, with submersion of ca $8 \mathrm{~h}$ per tidal cycle. During the experiments (July to October 1984), water temperatures ranged from 13 to $20^{\circ} \mathrm{C}$, and salinity remained close to $30 \%$. Sediments are relatively coarse-grained (median $0.55 \mathrm{~mm}$ ) with a decrease in particle size towards the low water line, and with a variable amount of shell gravel. Mussel beds were nearby and accumulated mud on their leeward sides.

The macrofauna of the more sandy sites was dominated by the orbiniid polychaete Scoloplos armiger (hereafter referred to as Scoloplos assemblage), and closer to the mussel beds by the capitellid polychaete 
Heteromastus filiformis (Heteromastus assemblage) Both Nephtys hombergii and N. caeca (Fabricius) are abundant in the area. However, the latter is almost entirely confined to the subtidal sediments, and in the following we only deal with $N$. hombergii (hereafter referred to as Nephtys) in the intertidal zone.

Gut content analysis and prey-choice experiments. Nephtys were individually fixed in ethanol $(70 \%)$ within $30 \mathrm{~min}$ after collection. The fixation caused some specimen to evert their pharynx, though regurgitation of recently swallowed food was not observed. Body length and volume was recorded. Individuals were cut in the mid-body region and gut content was squeezed out for microscopic analysis. Prey organisms were identified by undigestible parts, such as polychaete setae, amphipod and nematode cuticles.

Prey-choice experiments were conducted in the laboratory with Nephtys in sieved sand and polychaete prey added to the containers. These were closed with a $0.125 \mathrm{~mm}$ mesh and kept for $6 \mathrm{~d}$ under running seawater. Subsequently, polychaetes were counted and Nephtys was subjected to gut analysis.

Enclosure experiments. Bottomless buckets of $30 \mathrm{~cm}$ diameter $\left(0.07 \mathrm{~m}^{2}\right)$ were pressed $25 \mathrm{~cm}$ into the natural sediment, flush with the ambient surface. To some buckets Nephtys was added while the others served as controls (see Ambrose 1984a). Buckets were arranged in a regular grid with treatments and controls alternating. Sediment from each bucket was sieved with a $1 \mathrm{~mm}$ mesh and the retained macrofauna was identified and counted. Abundances are compared with a non-parametric U-test after Wilcoxon \& Whitney (Sachs 1984).

Enclosure Experiment 1. This experiment lasted $10 \mathrm{~d}$. Twenty-one buckets were pressed into the sediment of the Scoloplos assemblage. Seven received 16 small Nephtys $\left(<100 \mathrm{~mm}\right.$ or $0.8 \mathrm{~cm}^{3}$, average $60 \mathrm{~mm}$ or $0.4 \mathrm{~cm}^{3}$ ) each, another 7 received 6 large Nephtys (>100 mm or $0.8 \mathrm{~cm}^{3}$, average $120 \mathrm{~mm}$ or $1.1 \mathrm{~cm}^{3}$ ) each and the remaining 7 buckets served as controls without Nephtys added. The numbers of added small and large Nephtys were chosen to give an equal amount of biomass: the weight of 2.7 small Nephtys corresponds to the weight of 1 large Nephtys. All buckets were covered with a $1 \mathrm{~mm}$ mesh gauze. The addition of 16 small Nephtys resulted in a 7 -fold increase relative to control buckets. No large Nephtys were present in the control buckets and altogether 5 were found in the treatment with small Nephtys. Thus the addition of 6 large Nephtys per bucket constituted at least an 8-fold increase in the abundance of large Nephtys. At the end of the experiment, a total of 115 small and 40 large Nephtys were found in their respective treatments. This indicates that almost all added individuals remained inside and survived.
From each bucket 3 cores of $1 \mathrm{~cm}^{2} / 0$ to $5 \mathrm{~cm}$ were taken. In the laboratory seawater was added, the sample agitated and the supernatant repeatedly poured through a $0.08 \mathrm{~mm}$ sieve. Meiofauna was identified to major taxon and counted. For comparisons all 3 samples per bucket were pooled. Three cores of $10 \mathrm{~cm}^{2} / 0$ to $15 \mathrm{~cm}$ from each bucket were treated similarly but washed through a $0.25 \mathrm{~mm}$ sieve. Small macrofauna was identified and counted. The remaining sediment was sieved for large macrofauna ( $>1 \mathrm{~mm}$ ).

Enclosure Experiment 2. Duration of this experiment was $43 \mathrm{~d}$. Twelve buckets were pressed into the sediment of the Scoloplos assemblage, and 5 large Nephtys (as defined above) were added to each of 6 buckets. The other buckets served as controls. Buckets were covered with a $1 \mathrm{~mm}$ mesh. At the end of the experiment a total of 23 large Nephtys were found in the treatments. Thus possibly 7 individuals were lost. Abundance constituted approximately a 10 -fold increase relative to natural density. Adjacent to the experimental grid, 6 samples equal in size to the buckets were taken to test for bucket artifacts.

Enclosure Experiment 3. Twenty buckets were pressed into the sediment of the Heteromastus assemblage and every other bucket received 1 additional large Nephtys (see above). The buckets remained $58 \mathrm{~d}$ in the sediment and were not covered with gauze. A preliminary test with such topless buckets revealed that Nephtys remained inside even when confined at high densities. To test whether other macrofaunal densities were a function of Nephtys abundance or biomass within the buckets, Spearman's rank correlation coefficients were calculated (Sachs 1984).

Exclusion of large epibenthic predators. Twelve tin frames of $50 \times 50 \mathrm{~cm}$ were pressed $20 \mathrm{~cm}$ into the sediment of the Scoloplos assemblage, almost flush with the surface. Ten large Nephtys (see above) were added to each, and 6 frames were covered with chicken wire (30 $\mathrm{mm}$ meshes) to protect the enclosed fauna from large predators such as crabs (Carcinus maenas L.), flatfish and birds. After $60 \mathrm{~d}$ the sediment of the topless frames and of the cages was excavated and Nephtys were collected by hand.

\section{RESULTS}

\section{Abundance and biomass of Nephtys hombergii and its prey}

Natural density of Nephtys was up to 15 ind $\mathrm{m}^{-2}$ with a corresponding biomass of $1.1 \mathrm{~g}$ ash-free dry weight $\mathrm{m}^{-2}$. To estimate average abundance, $58 \mathrm{~m}^{2}$ were dug up with a fork and Nephtys was collected by hand. A mean of $5.2 \pm 4.5 \mathrm{~m}^{-2}$ corresponding to 0.36 
$\pm 0.3 \mathrm{~g} \mathrm{~m}^{-2}$ was obtained. Length and weight of the largest individual was $190 \mathrm{~mm}$ and $290 \mathrm{mg}$ respectively. On average, length was $64 \pm 23 \mathrm{~mm}$ and weight was $69 \pm 47 \mathrm{mg}$ per individual.

To estimate macrofaunal abundance in the study area, 40 core samples of $0.07 \mathrm{~m}^{2} / 0$ to $25 \mathrm{~cm}$ were sieved through a $1 \mathrm{~mm}$ mesh. A mean of $1400 \pm 700 \mathrm{~m}^{-2}$ was obtained. In the Scoloplos assemblage, S. armiger comprised $600 \mathrm{~m}^{-2}$ or $45 \%$ of total macrofauna. Other abundant species were the polychaete Lanice conchilega (Pallas) and the amphipod Corophium arenarium Crawford. In the Heteromastus assemblage, H. filiformis comprised $800 \mathrm{~m}^{-2}$ or $43 \%$ of the total. Other abundant species were the polychaete Tharyx marioni (Saint-Joseph) and the oligochaete Tubificoides benedeni (D'Udekem).

Less abundant species present in both assemblages were the polychaetes Nereis virens (Sars) and $N$. diversicolor (O. F. Müller), Eteone longa (Fabricius) and Anaitides mucosa (Obersted), all of which are predators on the infauna, just as Nephtys. This also applies to the nemertines Lineus viridis Johnston and Amphiporus lactifloreus (Johnston). The lugworm Arenicola marina (L.) was present with very large, deep dwelling individuals. Common bivalves found were Mytilus edulis (L.), Cerastoderma edule (L.), Macoma balthica (L.), Mya arenaria (L.) and Ensis directus (Conrad).

\section{Gut contents and choices of prey}

Out of 218 Nephtys investigated the guts of 145 $(67 \%)$ were empty, i.e. without animal prey or any other potential food particles. In the Scoloplos assemblage $19 \%$ (27 individuals) contained remains of $S$. armiger, $8 \%$ (11) of Heteromastus filiformis and $3 \%$ (4) of nematodes in their guts, while $70 \%$ (99) were empty. In one case, a Corophium arenarium and a proseriate plathelminth was found. In the Heteromastus assemblage, $23 \%(18$ individuals $)$ contained remains of $H$. filiformis, $10 \%$ (8) of nematodes, $6 \%$ (5) of $S$. armiger and the gut was empty in $60 \%$ (46) of the cases.

Nematodes were relatively frequent in the smallest Nephtys analysed, while the larger ones contained little other than remains of Scoloplos armiger and Heteromastus filiformis in their guts (Fig. 1). Because of their small size, nematodes do not seem to constitute a major prey, even in the smaller Nephtys. In 2 cases it appeared that nematodes were inside the intestines of a swallowed $H$. filiformis. We found also one case where Nephtys had swallowed the phyllodocid Eteone longa which in turn had swallowed the spionid Pygospio elegans (Claparede).
Prey-choice experiments in the laboratory revealed that Scoloplos armiger, Heteromastus filiformis and Anaitides mucosa were eaten by Nephtys. S. armiger often remained alive, but the tail ends were missing when kept together with Nephtys. This suggests tailcropping by Nephtys rather than ingestion of entire prey individuals when these are fairly large. $A$. mucosa evidently was eaten; however, no setae of this species were ever found in the guts of Nephtys.
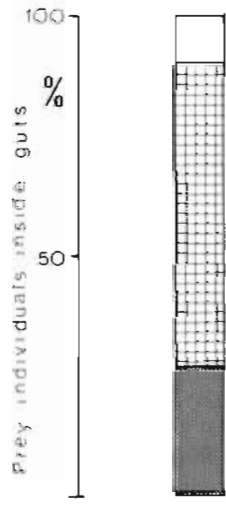

1

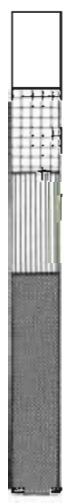

2



3

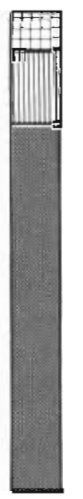

4

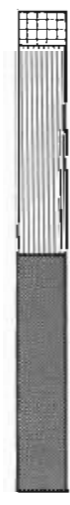

5
Fig. 1. Nephtys hombergii Percentage of prey individuals (dark: Scoloplos armiger, striated: Heteromastus filiformis, squared: nematodes; white: others) found in the guts of 73 Nephtys of the following size classes: $1(<20 \mathrm{mg}$ ); 2 (20 to $45 \mathrm{mg}$ ); 3 (45 to $70 \mathrm{mg}$ ); 4 (70 to $95 \mathrm{mg}$ ) and 5 (>95 mg) in terms of ash-free dry weight

\section{Enclosure experiments}

The enclosure of small and large Nephtys in the Scoloplos assemblage over a period of $10 \mathrm{~d}$ caused a significant decline in the densities of $S$. armiger and Anaitides mucosa (Fig. 2). A decrease in total macrofauna abundance was significant only with small Nephtys added to the enclosures. However, the relative composition of the macrofauna was changed markedly, regardless of whether small or large Nephtys were added. No significant effects of the Nephtys addition could be found for the small macrofauna $1<0.25$ mm) which was dominated by the 0 -groups of cockles and $S$. armiger. Neither were there any significant treatment effects detectable on meiofauna $(<0.08 \mathrm{~mm})$ which was entirely dominated by nematodes $(75 \%$ of abundance).

The second enclosure experiment in the Scoloplos assemblage lasted considerably longer (43 d), and only large Nephtys were added. Compared to control buckets macrofaunal density declined significantly in the presence of Nephtys (Table 1). This time, $S$. 


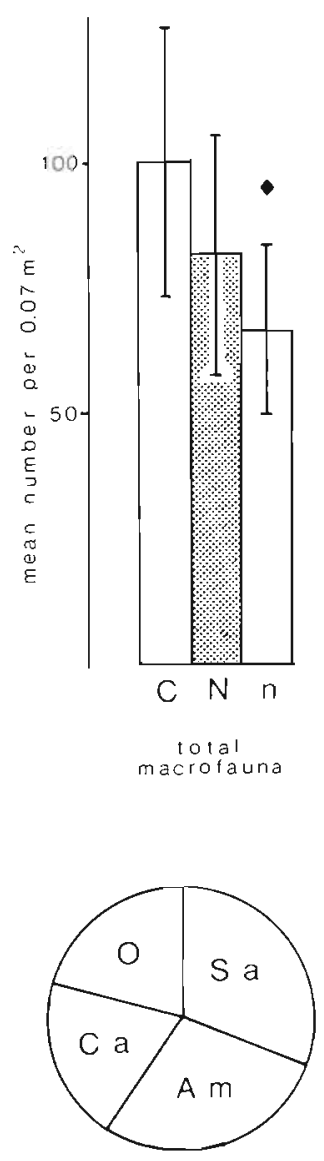

C



Scoloplos armiger
10 days

C Control buckets

$N \quad 6$ large Nephtys added

n 16 small Nephiys addea

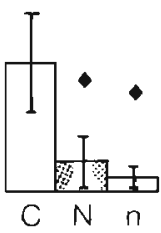

Anallides mucosa

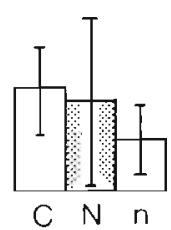

Corophium arenarium

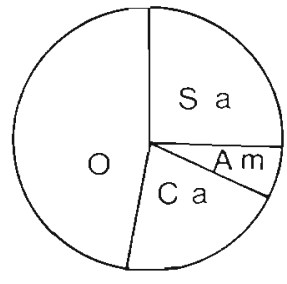

N

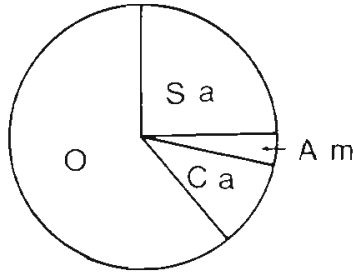

n
Fig. 2. Effects of enclosed small and large Nephtys hombergiu on other macrofauna (>1 mm) after $10 \mathrm{~d}$. $(\bullet)$ indicates a significant difference relative to control (Utest, $\mathrm{p}<0.05$ ); column height $=$ mean abundance; vertical line $=$ standard deviation $(n=7)$. Circles depict relative abundances within treatments: $\mathrm{Sa}=$ Scoloplos armiger, $\mathrm{Am}=$ Anaitides mucosa, $\mathrm{Ca}=$ Corophium arenarium, $\mathrm{O}=$ other macrofauna. Tidal flat in

Königshafen, summer 1984

Table 1. Numbers (means [SD] per $0.07 \mathrm{~m}^{-2}$ ) of benthic organisms found at termination of second experiment. P: Polychaeta; C: Crustacea; M: Mollusca; N: Nemertini

\begin{tabular}{|c|c|c|c|c|}
\hline & Species & Nephtys addition & Control buckets & Ambient sediment \\
\hline $\mathrm{p}$ & Nephtys hombergii (Savigny) & $4.2(1.3)$ & $0.8(0.8)$ & $0.3(0.2)$ \\
\hline \multirow[t]{2}{*}{$\mathrm{P}$} & Nereis diversicolor (Müller) juv. & $29.2(19.8)$ & $33.3(9.6)$ & $2.2(1.7)$ \\
\hline & ad. & $3.8(3.1)$ & $2.0(0.8)$ & $0.3(0.5)$ \\
\hline $\mathrm{P}$ & Scoloplos armiger (O. F. Müller) & $14.8(3.8)$ & $37.0(5.6)$ & $48.2(10.4)$ \\
\hline $\mathrm{P}$ & Heteromastus filiformis (Claparede) & $1.7(1.6)$ & $10.5(2.9)$ & $7.2(3.4)$ \\
\hline$P$ & Anaitides mucosa (Obersted) & $2.0(1.3)$ & $4.0(3.0)$ & $5.2(4.3)$ \\
\hline $\mathrm{P}$ & Lanice conchilega (Pallas) & $2.5(1.3)$ & $6.8(4.0)$ & $2.5(1.0)$ \\
\hline $\mathrm{P}$ & Arenicola marina (L.) & $0.8(0.7)$ & $0.3(0.5)$ & $0.4(0.5)$ \\
\hline$P$ & Eteone Ionga (Fabricius) & $1.2(0.7)$ & $2.7(1.1)$ & $1.7(0.7)$ \\
\hline $\mathrm{P}$ & Scolelepis squamata (Müller) & $0.3(0.5)$ & $0.2(0.4)$ & $0.2(0.4)$ \\
\hline$P$ & Tharyx marioni (D'Udekem) & 0 & $0.3(0.5)$ & 0 \\
\hline $\mathrm{P}$ & Small spionids & $0.8(1.2)$ & $1.3(1.6)$ & $0.3(0.4)$ \\
\hline $\mathrm{C}$ & Crangon crangon (L.) & $0.2(0.4)$ & $0.5(1.1)$ & 0 \\
\hline $\mathrm{C}$ & Corophium arenarium (Crawford) & $4.3(2.6)$ & $8.3(6.1)$ & $2.7(0.9)$ \\
\hline \multirow[t]{2}{*}{$\mathrm{C}$} & Carcinus maenas (L.) juv. & $6.8(5.3)$ & $11.7(9.6)$ & $0.5(0.5)$ \\
\hline & ad. & $0.7(0.5)$ & $0.2(0.4)$ & 0 \\
\hline $\mathrm{C}$ & Gammarus sp. & $0.2(0.4)$ & 0 & 0 \\
\hline M & Macoma balthica (L.) & $1.2(0.9)$ & $2.6(1.7)$ & $1.3(0.9)$ \\
\hline $\mathrm{M}$ & Littorina littorea (L.) & $0.5(0.8)$ & $0.7(0.7)$ & 0 \\
\hline $\mathrm{N}$ & Lineus viridis Johnston & $0.2(0.4)$ & $0.3(0.5)$ & 0 \\
\hline
\end{tabular}


Fig. 3. Effects of enclosed large Nephtys hombergii on other macrofauna after 43 d. For further explanation see Fig. 2
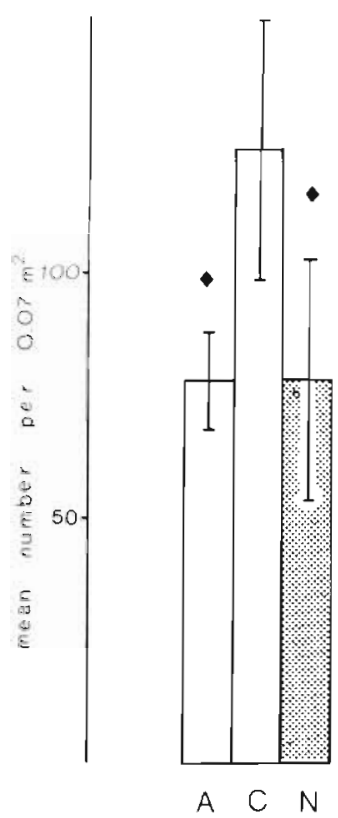

lotal macrotauna

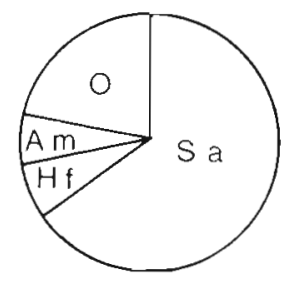

A
43 days

A Ambient Sediment

C Control buckels

N 5 large Nephtys added
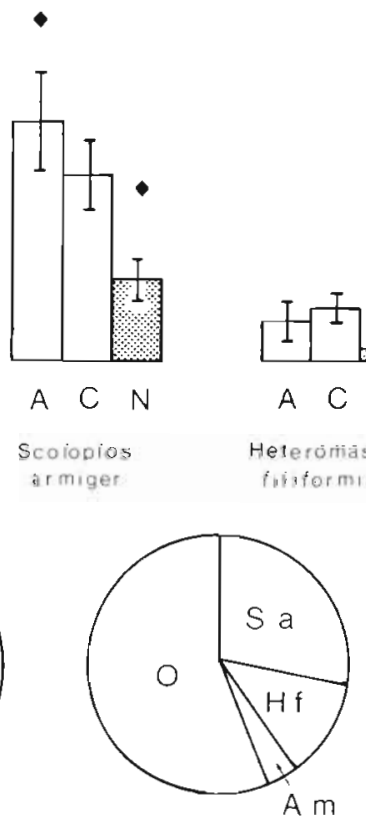

C

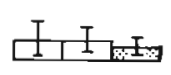

A C N

Anaitides mucosa

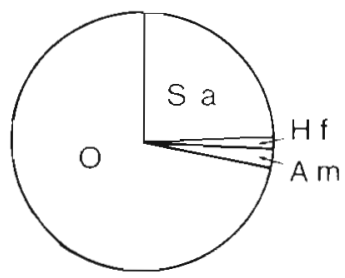

N armiger and Heteromastus filiformis showed significant treatment effects while Anaitides mucosa did not (Fig. 3). The comparison with ambient sediment revealed bucket artifacts. Macrofauna was significantly more abundant inside control buckets, mainly because of high immigration rates by early settling stages of Nereis diversicolor and the crab Carcinus maenas. Both were also highly abundant in the Nephtys treatment. Nephtys obviously did not prey on these juveniles. Another bucket artifact is a significantly decreased density of $S$. armiger, possibly caused by altered sediment properties.

The third enclosure experiment was done in the Heteromastus assemblage. One large Nephtys was added to each of 10 buckets out of 20. This time artifacts were avoided because the buckets were not covered with gauze. This addition treatment remained within the natural variability of Nephtys abundance. After $58 \mathrm{~d}$ a range of 0 to 4 Nephtys were found per bucket, and the addition treatment did not result in a consistently elevated density. Assuming that the abundance of Nephtys within buckets at the end of experiment corresponds with predation pressure inside these buckets, a correlation analysis was conducted. Spearman rank correlations indicate negative

Table 2. Linear regressions and Spearman's rank correlation coefficients (r) for Nephtys abundance (NA) and biomass (NB) and macrofaunal prey abundance (y), calculated from buckets in the Heteromastus assemblage, 10 of which had received 1 additional large Nephtys $58 \mathrm{~d}$ before. $\mathrm{y}=\mathrm{a}+\mathrm{bx}$ where $\mathrm{x}=\mathrm{NA}$ or $\mathrm{NB} ; \mathrm{a}, \mathrm{b}=$ coefficients. ${ }^{-} \mathrm{p}<0.05 ;{ }^{\cdots} \mathrm{p}<0.01$ for $\mathrm{r}_{\mathrm{s}}$

\begin{tabular}{|lrrr|}
\hline \multicolumn{1}{|c}{$\mathrm{x} ; \mathrm{y}$} & $\mathrm{a}$ & $\mathrm{b}$ & $\mathrm{r}_{\mathrm{s}}$ \\
\hline NA; total macrofauna & 124.8 & -15.1 & $-0.470^{\circ}$ \\
NB; total macrofauna & 120.5 & -0.95 & $-0.405^{\circ}$ \\
NA; Scoloplos & 33.8 & -3.50 & -0.249 \\
NB; Scoloplos & 36.7 & -0.39 & $-0.517^{\circ}$ \\
NA; Scoloplos biomass & 0.3 & -2.81 & -0.112 \\
NB; Scoloplos biomass & 0.42 & -0.56 & $-0.494^{\circ}$ \\
NA; Heteromastus & 52.8 & -10.7 & $-0.425^{\circ}$ \\
NB; Heteromastus & 51.9 & -0.76 & $-0.523^{\circ}$ \\
NA; Scoloplos \& Heteromastus & 86.6 & -14.2 & $-0.564^{\circ}$ \\
NB; Scoloplos \& Heteromastus & 88.6 & -1.15 & $-0.582^{\circ}$ \\
NA; other macrofauna & 38.2 & -0.87 & -0.102 \\
NB; other macrofauna & 31.9 & 0.20 & 0.143 \\
\hline
\end{tabular}


effects of Nephtys abundance and Nephtys biomass on the densities of Scoloplos armiger and $H$. filiformis but not on other macrofauna (Table 2).

\section{Epibenthic predation on Nephtys}

Cages covered with $30 \mathrm{~mm}$ chicken wire retained significantly more individuals of Nephtys than the topless cages $(8.5 \pm 1.5$ versus $5.7 \pm 1.3$; U-Test: $p<0.05$ ). This corresponds to a decrease of $33 \%$ in Nephtys abundance within $60 \mathrm{~d}$, attributable to large epibenthic predators. The decrease in biomass was in the same range, but not significant $(0.8 \pm 0.2$ versus $0.5 \pm 0.2 \mathrm{~g})$

\section{DISCUSSION}

Our field experiments demonstrate that the endobenthic Nephtys hombergii does affect the density of other endobenthic macrofauna, while it is itself prey to large epibenthic predators. Gut content analysis confirmed that the investigated Nephtys are carnivores that prey mainly on other polychaetes.

\section{Artifacts of field experiments}

Our field experiments were not free of artifacts. Pressing buckets into the sediment injures or kills infauna. This attracts Anaitides mucosa which is a Carnivorous scavenger (see also Reise 1979a, b). In the first experiment, with a duration of only $10 \mathrm{~d}, A$. mucosa was 6 times more abundant in control buckets (25 [9] ind $0.07 \mathrm{~m}^{-2}$ ) than in the ambient sediment (4 [2] ind $0.07 \mathrm{~m}^{-\hat{2}}$ ). In the buckets with Nephtys added, A. mucosa was either eaten or scared away. This disturbance effect does not last very long, however, because all carrion is consumed or has decayed (after 3 to $4 \mathrm{wk}$ according to $\mathrm{M}$. Hütel unpubl.). Therefore, no elevated density of $A$. mucosa was observable at the end of the second experiment which lasted $43 \mathrm{~d}$.

An immigration of 0 -group Nereis diversicolor and Carcinus maenas occurred in treatments and controls alike. This event did not affect the experiment because neither was prey for Nephtys. In the $10 \mathrm{~d}$ experiment, almost all Nephtys survived. Enclosure over $43 \mathrm{~d}$ caused a loss of about $20 \%$.

\section{Diet of Nephtys}

Enclosure experiments and gut content analysis revealed that Nephtys preyed on the polychaetes Scoloplos armiger, Heteromastus filiformis, Anaitides mucosa, Eteone longa, on nematodes, a plathelminth and the amphipod Corophium arenarium. Ivlev-indices of prey selectivity are all positive for the polychaetes, both when gut content is compared to abundance in the sediment and when the difference between Nephtys enclosures and control buckets is considered. In a laboratory feeding experiment, Nephtys swallowed $H$. filiformis whole, while the larger $S$, armiger mainly sacrificed their tail ends (in one case the front end) to the predator. Gibbs (1968) observed that female $S$. armiger, regenerating a major portion of their body, contained only small immature oocytes just before the breeding season. Thus, tail-cropping will not only affect body-size but also fecundity in the prey population.

Small macrofauna and meiofauna do not seem to constitute a major component in the diet of adult Nephtys at Sylt (see also Reise 1979b). Only the smallest Nephtys investigated contained a high proportion of nematodes in their guts. A carnivorous habit of Nephtys is also suggested by the fact that most guts were empty.

Fauchald \& Jumars (1979) reviewed the feeding habits of nephtyids and consider the genus Nephtys to be composed primarily of predators. Polychaetes are frequently mentioned as prey for $N$. hombergii; however, small bivalves, crustaceans and forams have also been found in the guts (Blegvad 1914, Clark 1962, Ockelmann \& Muus 1978). Warwick \& Price (1975) found nematodes, ostracods, a small crab and diatoms within the guts of a population dwelling in the mud of the Lynher estuary (England). In a simulation model for the energy flow through this estuarine benthos, Warwick et al. (1979) discovered that there was not enough meiofaunal and macrofaunal prey to maintain this Nephtys population. As a solution, they suggested that $N$. hombergii feeds primarily on phytobenthos.

The population density on the Lynher mud flat was much higher $\left(855 \mathrm{~m}^{-2}\right)$ than the one on the Sylt sandy flat $\left(5 \mathrm{~m}^{-2}\right)$. This difference is not limited to a stronger 0 -group $(82 \%$ in the Lynher versus $44 \%$ at Sylt), which may to some extent originate from different methods (sieving versus collection by hand), but also the $1+$ groups are at least 10 times more abundant on the Lynher mud flat compared to the sand flat near Sylt. Apparently, these Nephtys hombergü seem to behave quite differently. Either this species switches to omnivory in certain habitats and when population density becomes high, or Nephtys hombergui in fact comprises more than one species.

\section{Estimates of consumption}

Consumption rates were not measured directly. However, a very rough estimate may be obtained from the enclosure experiments. Assuming that Nephtys 
prey on other macrofauna during 9 mo of the year (winter excluded) and that feeding rates of Nephtys within enclosures approximate natural rates, then 60 to 80 prey individuals are consumed annually by a medium sized Nephtys (Table 3). In other words, every 3 to $4 \mathrm{~d}$ one prey individual in the macrofaunal size range is eaten

Table 3. Nephtys hombergii. Amount of prey consumed by 1 Nephtys over $9 \mathrm{mo}$, calculated from differences between control buckets and the Nephtys treatments (Experiment 1 and 2) and the slope of regression lines (Experiment 3). n: small; N: large Nephtys added

\begin{tabular}{|lrrrrr|}
\hline \multicolumn{1}{|c}{ Prey components } & \multicolumn{5}{c}{ Experiment } \\
& 1n & $1 \mathrm{~N}$ & $2 \mathrm{~N}$ & \multirow{2}{*}{$3 \mathrm{~N}$} \\
\hline Total macrofauna (ind) & 61 & 81 & 64 & 68 \\
Scoloplos armiger (ind) & 26 & 58 & 29 & 16 \\
Scoloplos armiger (mg) & 320 & 730 & 300 & 240 \\
Heteromastus filiformis (ind) & - & - & - & 49 \\
Heteromastus filiformis (mg) & - & - & - & 240 \\
\hline
\end{tabular}

In the Scoloplos assemblage $S$. armiger was the dominant prey and consumption rate is estimated at 38 prey individuals annually, corresponding to an ashfree dry weight of $400 \mathrm{mg} \mathrm{yr}^{-1}$. This will be an underestimate, because tail-cropping is not included. On the other hand, potential prey individuals may have escaped from the buckets before Nephtys could get them (see Ambrose 1984d). This is likely to be the case with the surface-mobile Anaitides mucosa but not with the subsurface-feeding $S$. armiger and Heteromastus filiformis. S. armiger comprised about $60 \%$ of all macrofaunal prey, thus the total biomass consumed is probably about $700 \mathrm{mg} \mathrm{yr}^{-1}$.

With a population density of 5 Nephtys $\mathrm{m}^{-2}$, total macrofauna consumed is in the order of 300 to 400 prey individuals $\mathrm{m}^{-2} \mathrm{yr}^{-1}$. This is approximately 2.5 to $4.0 \mathrm{~g}$ $\mathrm{m}^{-2} \mathrm{yr}^{-1}$ in terms of ash-free dry weight or 1.0 to $1.6 \mathrm{~g}$ $\mathrm{C} \mathrm{m}^{-2} \mathrm{yr}^{-1}$. Starting with another set of assumptions for the Nephtys population (Warwick \& Price 1975, Beukema 1981), a P/B-ratio of 2 and an ecological efficiency of $20 \%$, the Nephtys biomass of $0.14 \mathrm{~g} \mathrm{C}$ $\mathrm{m}^{-2}$ is expected to consume $1.4 \mathrm{~g} \mathrm{C} \mathrm{m}^{-2} \mathrm{yr}^{-1}$.

These estimates may be compared to those published for epibenthic predators in the intertidal Wadden Sea $\left(\mathrm{g} \mathrm{C} \mathrm{m} \mathrm{m}^{-2} \mathrm{yr}^{-1}\right)$ : Carcinus maenas 2.0 (Scherer \& Reise 1981), Crangon crangon 2.7 (Kuipers \& Dapper 1981), fish 3 and birds 2 (Beukema 1981. Kuipers et al. 1981); about 10 altogether. Thus, in terms of biomass, the population of the endobenthic Nephtys hombergii consumes at least one tenth of all epibenthic predation combined.

\section{Predatory role of Nephtys}

Nephtyids are mostly vagile carnivores and have a very large eversible pharynx with a pair of small jaws (Fauchald \& Jumars 1979). They are capable of very fast burrowing and good swimming (Mettam 1967, Trevor 1976, Gibbs \& Bryan 1984). We have seen them rarely on the sediment surface, which suggests that hunting of prey occurs within the sediment. This mode of feeding excludes most surface-dwelling fauna and tube-building polychaetes (like Lanice conchilega) from their prey spectra.

Other field experiments with carnivorous or omnivorous polychaetes (Commito 1982, Ambrose 1984 a, b, Commito \& Shrader 1985) disclosed much trophic complexity lurking below the sediment surface. This makes it difficult to differentiate between direct and indirect effects of predator additions and removais. In the case of adult Nephtys hombergii on the sand flat near Sylt, the realized prey spectrum is rather narrow, and affected are primarily the established adult populations of 2 deposit-feeders. Scoloplos armiger and Heteromastus filiformis are more or less sedentary, feed below the surface and do not build solid tubes. In the Scoloplos assemblage we roughly estimate an annual consumption of 130 to $290 \mathrm{~S}$. armiger individuals $\mathrm{m}^{-2}$ which is 20 to $50 \%$ of its standing stock. In the Heteromastus assemblage, we estimate $245 \mathrm{~m}^{-2} \mathrm{H}$. filiformis individuals or about $30 \%$ of the standing stock are eaten annually. These estimates neglect the respective juvenile populations, as Nephtys seems to prey preferentially on adult individuals.

Nephtys hombergii also preys to some extent on other endobenthic predators, such as Anaitides mucosa and Eteone longa. These 2 and $N$. hombergii overlap in their prey spectra, with Nephtys being the top-predator relative to the others (M. Hüttel unpubl., authors' own data). It may be that these predators preyed more effectively in the control buckets than in the presence of Nephtys. This might mask some direct effects of Nephtys, and then our estimates on the amount of prey individuals eaten are too low. Nephtys is not the ultimate top-predator within this sediment. The nemertine Lineus viridis, also common on this sandy flat, has been observed to swallow Nephtys (W. Nordhausen unpubl.).

The above estimates imply that Nephtys hombergii deprives crabs, fish and birds of a substantial amount of their polychaete prey. On the other hand, nephtyids are known to be prey of crabs, fish and birds (Blegvad 1914, Bryant 1979, de Vlas 1979). This is substantiated by our caging experiments and documents the role of Nephtys as an intermediate predator (sensu Ambrose $1984 \mathrm{c}$ ) in the food chain of tidal flats. 


\section{LITERATURE CITED}

Ambrose, W. G. (1984a). Influences of predatory polychaetes and epibenthic predators on the structure of a soft-bottom community in a Maine estuary. J. exp. mar. Biol. Ecol. 81: $115-145$

Ambrose, W. G. (1984b). Influence of residents on the development of a marine soft-bottom community. J. mar. Res. 42: 633--654

Ambrose, W. G. (1984c). Increased emigration of the amphipod Rhepoxynius abronius (Barnard) and the polychaete Nephtys caeca (Fabricius) in the presence of invertebrate predators. J. exp. mar. Biol. Ecol. 80: 67-75

Ambrose, W. G. (1984d). Role of predatory infauna in structuring soft-bottom communities. Mar. Ecol. Prog. Ser. 17: 109-115

Beukema, J. J. (1981). The role of the larger invertebrates in the Wadden Sea ecosystem. In: Dankers, N., Kühl, H., Wolff, W. J. (ed.) Invertebrates of the Wadden Sea. Balkema, Rotterdam, p. 211-221

Blegvad, H. (1914). Food and conditions of nourishment among the communities of invertebrate animals found on or in the sea bottom of Danish waters. Rep. Dan. Biol. Stn 22: $41-78$

Bryant, D. M. (1979). Effects of prey density and site character on estuarine usage by wintering waders (Charadrii). Estuar. coast. Shelf Sci. 9: 369-384

Clark, R. B. (1962). Observations on the food of Nephtys. Limnol. Oceanogr. 7 : 380-385

Commito, J. A. (1982). Importance of predation by infaunal polychaetes in controlling the structure of a soft-bottom community in Maine, USA. Mar. Biol. 68: 77-81

Commito, J. A., Ambrose, W. G. (1985a). Predatory infauna and trophic complexity in soft-bottorn communities. In: Gibbs, P. E. (ed.) Proc. 19th Europ. Mar Biol. Symp., Cambridge Univ. Press, Cambridge, p. 323-334

Commito, J. A., Ambrose, W G. (1985b). Multiple trophic levels in soft-bottom communities. Mar. Ecol. Prog. Ser. 26: $289-293$

Commito, J. A., Shrader, P. B. (1985). Benthic community response to experimental additions of the polychaete Nereis virens. Mar. Biol. 86: 101-107

Fauchald, K., Jumars, P. A. (1979). The diet of worms: a study of polychaete feeding guilds. Oceanogr. mar. Biol. A. Rev. 17: $193-284$

Gibbs, P. E. (1968). Observations on the population of Scoloplos armiger at Whitstable. J. mar biol. Ass. U.K. 48: 225-254

Gibbs, P. E., Bryan, G. W. (1984). Calcium phosphate granules in muscle cells of Nephtys (Annelida, Polychaeta) - A novel skeleton? Nature, Lond. 310: 494-495

Kuipers, B. R., de Wilde, P. A. W. J., Creutzberg, F. (1981). Energy flow in a tidal flat ecosystem. Mar. Ecol. Prog. Ser 5: $215-221$
Kuipers, B. R., Dapper, R. (1981). Production of Crangon crangon in the tidal zone of the Dutch Wadden Sea. Neth. J. Sea Res. 15: 33-35

McGrorty, S., Reading, C. J. (1984). The rate of infill and colonization by invertebrates of burrow pits in the Wash (S.E. England). Estuar. coast. Shelf Sci. 19: 303-319

Mettam, C. (1967). Segmental musculature and parapodial movement of Nereis diversicolor and Nephtys hombergii (Annelida, Polychaeta). J. Zool., Lond. 153: 243-275

Ockelmann, K. W., Muus, K. (1978). The biology, ecology and behaviour of the bivalve Mysella bidentata (Montagu). Ophelia 17: 1-93

Peterson, C. H. (1979). Predation, competitive exclusion and diversity in the soft-bottom communities of estuaries and lagoons. In: Livingstone, R. J. (ed.) Ecological processes in coastal and marine systems. Plenum Press, New York, p. 233-264

Reise, K. (1979a). Spatial configurations generated by motile benthic polychaetes. Helgoländer wiss. Meeresunters. 32: 55-72

Reise, K. (1979b). Moderate predation on meiofauna by the macrobenthos of the Wadden Sea. Helgoländer wiss. Meeresunters. 32: 453-465

Reise, K. (1985a). Predator control in marine tidal sediments. In: Gibbs, P. E. (ed.) Proc. 19th Europ. Mar. Biol. Symp. Cambridge Univ. Press, Cambridge, p. 311-322

Reise, K. (1985b). Tidal flat ecology. Springer Verlag, Heidelberg, p. 1-191

Sachs, L. (1984). Angewandte Statistik. Springer Verlag, Berlin, p. 1-552

Scherer, B., Reise, K. (1981). Significant predation on microand macrobenthos by the crab Carcinus maenas $\mathrm{L}$. in the Wadden Sea. Kieler Meeresforsch. (Sonderh.) 5: 490-500

Trevor, J. H. (1976). The burrowing activity of Nephtys cirrosa Ehlers (Annelida, Polychaeta). J. exp. mar. Biol. Ecol. 24: $307-319$

Vlas, J. de (1979). Annual food intake by plaice and flounder in a tidal flat area in the Dutch Wadden Sea, with special reference to consumption of regenerating parts of macrobenthuc prey. Neth. J. Sea Res. 13: 117-153

Warwick, R. M., Joint, I. R., Radford, P. J. (1979). Secondary production of the benthos in an estuarine environment. In: Jefferies, R. L., Davy, A. J. (ed.) Ecological processes in coastal environments. Blackweil Scientific Publ., Oxford, p. 429-450

Warwick, R. M., Price, R. (1975). Macrofauna production in an estuarine mud-flat. J. mar. biol. ass. U.K. 55: 1-18

Wohlenberg, E. (1937). Die Wattenmeer-Lebensgemeinschaften im Königshafen von Sylt. Helgoländer wiss. Meeresunters. 1: 1-92

Woodin, S. A. (1983). Biotic interactions in recent marine sedimentary environments. In: Tevesz, M. J. S., McCall, P. L. (ed.) Biotic interactions in recent and fossil benthic communities. Plenum Press, New York, p. 3-38 